\title{
ETNOCARTOGRAFIA NA COSTA PACIFICA DA COLÔMBIA. RE-MAPEANDO A RURALIDADE NO MUNICÍPIO DE LOPEZ DE MICAY CAUCA
}

\author{
ETNOCARTOGRAFIA EN LA COSTA PACÍFICA DE COLOMBIA. \\ RE-MAPEANDO LA RURALIDAD EN EL MUNICIPIO \\ DE LÓPEZ DE MICAY-CAUCA
}
ETNOCARTOGRAPHY IN THE PACIFIC COAST OF COLOMBIA. REMAPPING RURALITY IN THE MUNICIPALITY OF LÓPEZ DE MICAY - CAUCA

\begin{abstract}
Jesica Wendy Beltrán
Mestre pela Universidade Federal de Santa Maria, RS, Brasil. Professora no departamento de Engenheria Forestal na Universidade do Cauca. Colombia. Endereço: Carrera 8 c \# 23-04, Barrio sindical, segunda etapa, ,Popayan-Cauca, Colombia; Código postal: 190003.

e-mail: jessi120bel@hotmail.com
\end{abstract}

\section{Cesar De David}

Pós-doutorado pela Université du Maine-Le Mans (Franca). Professor associado pela Universidade Federal de Santa Maria, e líder do Grupo de Pesquisa em Educação e Território-GPET. Endereço: Universidade Federal de Santa Maria, Centro de Ciências Naturais e Exatas, Departamento de Geociências. Av. Roraima - Prédio 17 - Sala 1017, Cidade Universitária, 97105-900 - Santa Maria, RS - Brasil. Universidade Federal de Santa Maria, RS.e-mail: cdedavid2009@gmail.com

\begin{abstract}
Resumo
A Etnocartografia na Costa Pacífica da Colômbia é uma pesquisa que tem como área de estudo o Pacifico Caucano e mais especificamente o município de Lopez de Micay. Por suas características de floresta úmida tropical, por sua grande biodiversidade, por albergar comunidades ancestrais negras e indígenas, pela pobreza e pela violência armada, o Pacifico se converte em um lugar único, sendo este o ponto de partida para as nossas reflexões sobre a ruralidade na contemporaneidade. A Cartografia Social como metodologia, representou um instrumento central para revelar o conhecimento local sobre o uso do espaço de floresta por parte das comunidades negras, sendo este o grupo étnico de estudo. Dessa forma o objetivo central se focou em analisar e reconstruir com a comunidade afrocolombiana, por meio da Cartografia Social, o conceito de Ruralidade, o qual teve como resultado os encontros e desencontros entre o saber local e saber da "ciência", mostrando que esta última carece de ferramentas e elementos de análises para poder explicar a ruralidade neste espaço.
\end{abstract}

Palavras chave: Cartografia Social, Costa Pacifica, Comunidades Negras, Ruralidade. 


\title{
Resumen
}

La Etnocartografia en la Costa Pacífica de Colombia es una investigación que tiene como área de estudio el Pacifico caucano, específicamente el municipio de López de Micay. Por sus características de selva húmeda tropical, por su grande biodiversidad, por albergar comunidades ancestrales negras e indígenas, por la pobreza y por la violencia armada, el Pacifico se convierte en un lugar único, este es el punto de partida para las reflexiones sobre la ruralidad en la contemporaneidad. La Cartografía Social como metodología, representó un instrumento central para revelar el conocimiento local sobre el uso del espacio selvático por parte de las comunidades negras, siendo este, el grupo étnico de estudio. De esa forma el objetivo central se foco en analizar y reconstruir con la comunidad afrocolombiana, por medio de la Cartografía Social, el concepto de Ruralidad, el cual tuvo como resultado los encuentros y desencuentros entre el saber local y el saber de la "ciencia", mostrando que este último carece de herramientas y elementos de análisis que puedan explicar la ruralidad en ese espacio.

Palabras clave: Cartografía Social, Costa Pacífica, Comunidades Negras, Ruralidad.

\begin{abstract}
The ethno-mapping on the Pacific Coast in Colombia is an investigation that has as study area in the Cauca Pacific, specifically the town of López de Micay. Due to its characteristics of tropical rainforest for his great biodiversity, for harboring ancestral black and indigenous communities, by poverty and armed violence, the Pacific becomes a unique place, this is the starting point for reflections on rurality in contemporary times. The Social Mapping how methodology represented a central instrument to reveal the local knowledge about the use of wild space by black communities, and this, ethnic group study. Thus the central objective will focus on analyzing and rebuild with the Afro-Colombian community, through social mapping, the concept of rurality, which resulted in encounters and clashes between local knowledge and the knowledge of the "science" showing that the latter lacks analysis tools and elements that may explain the rurality in that space.
\end{abstract}

Keywords: social mapping, Costa Pacifica, Black Communities, Rurality. 


\section{INTRODUÇÃO}

A costa Pacífica na Colômbia é um território que se localiza a sudoeste do país. Esta região integra os departamentos de Choco, Valle del Cauca, Cauca e Nariño, totalizando uma extensão territorial de $1.300 \mathrm{~km} 2$. Situa-se numa altitude que varia desde o nível do mar até os 2.500 metros. Esta região, representada numa porção de território: o município de Lopez de Micay- departamento do Cauca (ver figura 1) possui características que o faz único, este município é mais rural que urbano, constitui-se em sua maioria por comunidades negras, que convivem em territórios coletivos reconhecidos pela Lei 70 de 1993, o qual lhe da o carácter étnico-territorial e de afro-colombianos ${ }^{1}$ as pessoas negras que o habitam. Este território também é reconhecido internacionalmente por ser parte de um dos biomas de maior importância para a Terra: o Chocó Biogeográfico. No entanto esta região coberta por exuberantes florestas e biodiversidade, é marcada pela marginalidade, pobreza e violência armada que expulsa de forma forçada a população que habita a floresta úmida tropical.

Figura 1: Localização município López de Micay -Cauca.

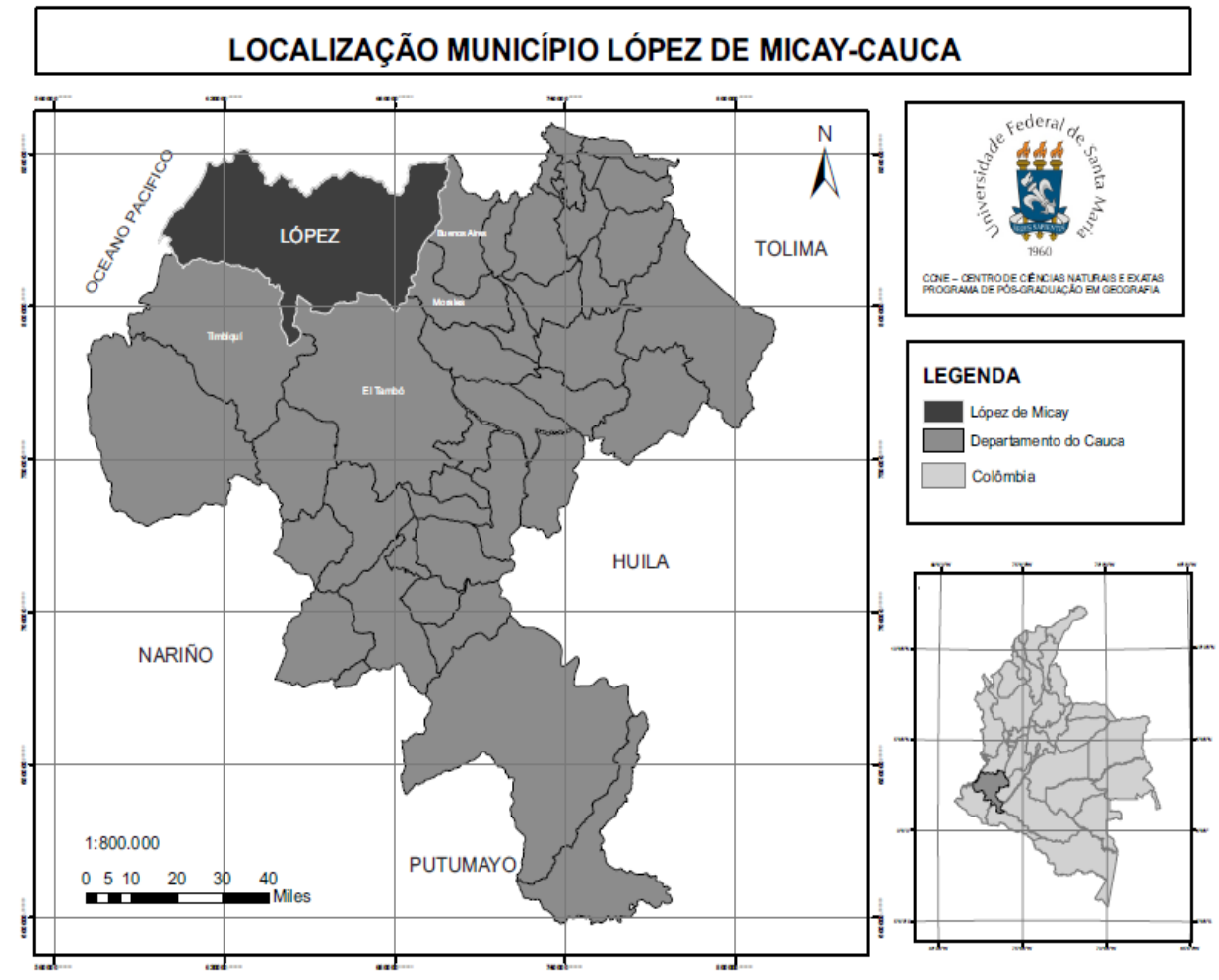

Fonte: Sistemas de Informação Geográfica para o planejamento Territorial-SIGOT

Organização: Jesica W. Beltran CH e Cesar de David

Ainda que o termo de afro-colombiano esta em discussão, o termo nesta pesquisa se entende como "a los actuales descendientes de los negros africanos, arrancados de su continente para ser traídos a América en calidad de esclavos, que aportaron su patrimonio cultural inmaterial al proceso de construcción de la esencia humana de los colombianos como residentes americanos (...) como resultado de la creación de tradiciones culturales que proviene de ancestros africanos, objeto de intercambio con los usos y costumbres indígenas y españoles que, como parte de la denominación afro, muestran un conjunto socio-cultural especifico" (OCAMPO et al. 2013, pg. 17) 
Outro dos apectos importantes do Pacífico é a insolação geográfica e econômica frente às dinâmicas territoriais do Estado Colombiano, o que permitiu a formação das comunidades negras, marcadas por uma cultura ancestral africana e caracterizada por manter práticas tradicionais no campo sujeitas à lógicas e saberes que se distanciam parcial ou totalmente das descrições do meio rural ligado à agricultura capitalista, de indústrias pequenas e medianas, comércio e serviços que se assentam em povos, cidades e centros regionais, espaços naturais e cultivados (PÉREZ, 2006), nas palavras de Barnett (2003) onde a globalização é débil ou está totalmente ausente (BARNETT, 2003 apud SERGE 2011).

Por outra parte, o que é considerado rural na contemporaneidade na Colômbia, carece de elementos para a compreensão de espaços rurais como os do litoral Pacífico, já que o entendimento sobre ruralidade e as diferentes realidades que se apresentam no mundo rural tem sido uma tarefa abordada com grande sucesso através do saber científico, das abstrações do conhecimento ocidental, hegemônico, e não através de quem faz parte destes espaços. Na atualidade explicar a ruralidade do Pacífico caucano através dos conhecimentos científicos não são suficientes; assim o saber local se mostra como o caminho para encontrar outros entendimentos e outras formas de conceber a ruralidade na contemporaneidade. Neste sentido, este trabalho não só privilegia o saber local como também deixa claro que "ficam indefinidos não só os limites entre as ciências, mas, também, entre diferentes modos de conhecer, já não sendo possível traçar com tanta certeza o limite entre quem sabe e quem não sabe" (PORTO, 2002 pg. 221).

Neste contexto refletimos sobre a nuances envoltas as interpretações científicas à cerca desta comunidade culturalmente diversa, marcada por conflitos e tradições, com a finalidade de chegar a uma compreensão da ruralidade, na medida em que se questiona a configuração desta no mundo contemporâneo.

$\mathrm{Na}$ primeira parte se expoe a metodologia usada para abordar esta pesquisa, a qual esta direcionada no uso da Cartografia Social, a qual envolve o mapeamento participativo, possibilitaram a criacao de mapas carregados de simbolismos, que representa em alguma medida o espaco de floresta do litoral Pacifico.

O segundo apartado faz referencia aos resultados da Cartografia Social feita pela comunidade afro colombiana, na qual se descreve o espaço de floresta e o rural no Pacifico e mais especificamente no município de Lopez de Micay.

O terceiro apartado descreve as reflexões sobre o rural no litoral pacifico da Colômbia, onde a Floresta tropical é considerada uma categoria espacial do espaço rural, que explica a existência de espaços diferenciados, onde se considera a parte física, social e simbólica para puder interpreta-lo. Por ultimo se apresentam as considerações finais. 


\section{METODOLOGIA}

A forma de interpretar esta realidade sujeita a um método e metodologia, se baseia na Geografia da percepção, e mais especificamente nos conceitos de Kevin Linch (1960), e partindo do fato de que o espaço é uma construção social, que deve ser entendido frente às subjetividades das pessoas que o habitam.

Tal colocação está sustentada na teoria geográfica da percepção, a qual nasce com os trabalhos dos geógrafos humanistas, Yi Fu Tuan (1974), Kevin Lynch (1960), Edwar Soja (1990), e Henri Lefevre (1974), que discutem a concepção do espaço a partir de conceitos como: espaço concebido, percebido e vivido de Lefevre, os mapas mentais de Lynch, os conceitos de topofilia e topofobia de Tuan entre outros.

A percepção por tanto se torna um meio pelo qual as pessoas constróem uma imagem do espaço, que por sua vez pode ser representado, como fruto do contato bilateral entre o ambiente e o observador, o qual também permite gerar uma imagem mais legível ou nítida (LYNCH, 1960), pois as relações entre homem-meio se intensificam com a experiência com o cotidiano, permitindo estruturar o espaço numa imagem clara e totalmente ordenada. Uma imagem legível que seja coletiva vai permitir mostrar o consenso que se tem sobre o conhecimento, a ordenação e significação do espaço numa determinada comunidade. A partir desta abordagem, a cartografia social aparece como metodologia participativa, já que se faz necessário abordar este tipo de pesquisas com uma metodologia que possibilite um diálogo e aproximação com a comunidade, que valorize o conhecimento local e que permita deslumbrar esses saberes sobre o espaço rural e sua configuração codificada em simbolismos que foram possíveis decifrar. Pois a Cartografia Social como metodologia participativa é adequada para trabalhar com grupos locais, que em seu processo vão se resinificando o território, gerando conhecimento através da geração de mapas temáticos feitos pela comunidade.

Por conseguinte a Cartografia Social se estabeleceu como a ferramenta e o processo, por meio do qual a comunidade negra do município de Lopez de Micay construiu mapas sobre suas praticas agrícolas, seu território, e a ordenação do mesmo.

\section{Processo de construção de mapas.}

A elaboração participativa dos mapas no município de Lopez de Micay esteve encaminhada à construção de desenhos do uso da terra no município.Seguiram-se três fases para realizar as oficinas de Cartografia Social: pré-mapeamento, mapeamento e socialização. 
O pré-mapeamento, correspondeu a conversações informais nas quais se realizaram entrevistas com diferentes pessoas da comunidade e com representantes dos conselhos comunitários $^{2}$. Explicaram-se o motivo e os objetivos da pesquisa e a dinâmica de como se realizaria a oficina, para logo abordar diferentes temáticas sobre o território e uso do solo. Houve um diálogo a respeito da localização das atividades e dos diferentes usos da terra. Também se realizaram visitas guiadas e não guiadas sobre o rio Micay, o centro povoado de Lopez de Micay, o centro povoado de Noanamito (sede do conselho comunitário Manglares), com a finalidade de conhecer o terreno, entender suas lógicas a partir das falas das pessoas que habitam este território e de vivenciar junto com eles seu cotidiano, sendo este um trabalho de observação.

Para o processo de mapeamento se forneceu a comunidade cartografia base, a qual consistiu num croqui ou esboço do município de Lopez de Micay a escala 1: 45.000. Nos mapeamentos tanto jovens quanto os adultos se integraram, estabelecendo um diálogo, em que discutiram aspectos da delimitação dos conselhos comunitários, nomes dos rios, localização dos centros povoados, nomes dos povoados, número de habitantes, extensão do território e os diferentes usos que desenvolvem. (ver figura 2)

Uma das características no processo de mapeamento é que o primeiro elemento que os mapeadores desenharam foi o rio principal do município: o Rio Micay, representado sobre a base principal do território, a partir do rio se desenharam seus afluentes e os rios principais dos conselhos comunitários: Playon do Rio Sigui, Integração do Rio Chuare e Manglares do Rio Micay, os quais correspondem aos rios Micay, Sigui, e Chuare. Nestes rios e nas suas margens se realizam atividades agrícolas, de pesca e de mineração, o rio representa as vias e o meio que possibilita seu deslocamento, por isso sua grande importância no processo de mapeamento. Na sequência, a partir do desenho da estrutura hidrográfica, desenharam os outros componentes do espaço do município, o que tornou possível diferenciar as unidades da paisagem, as quais são as zonas nas quais se divide o território através do Rio Micay: zona baixa, media e alta.

Também se desenharam sobre o eixo do Rio Micay os limites de alguns dos territórios que não são negros, os quais pertencem às comunidades indígenas, os quais são denominados: cabildos. Quanto ao uso do solo, os desenhos foram feitos a partir dos eixos dos rios em seus contornos e por camadas os usos da terra e os diferentes cultivos que ali se desenvolvem.

\footnotetext{
Os conselhos comunitários são instâncias de administração e manejo dos territórios coletivos que o Estado lhe tem outorgado às comunidades negras, o qual tem exigido por parte das comunidades negras uma reflexão e apropriação social e cultural desta ordenação sobre o território negro (ARIZA, et al 1999).
} 
Figura 2. Mapa confeccionado pelos representantes dos conselhos comunitários do municipío de Lopez de Micay

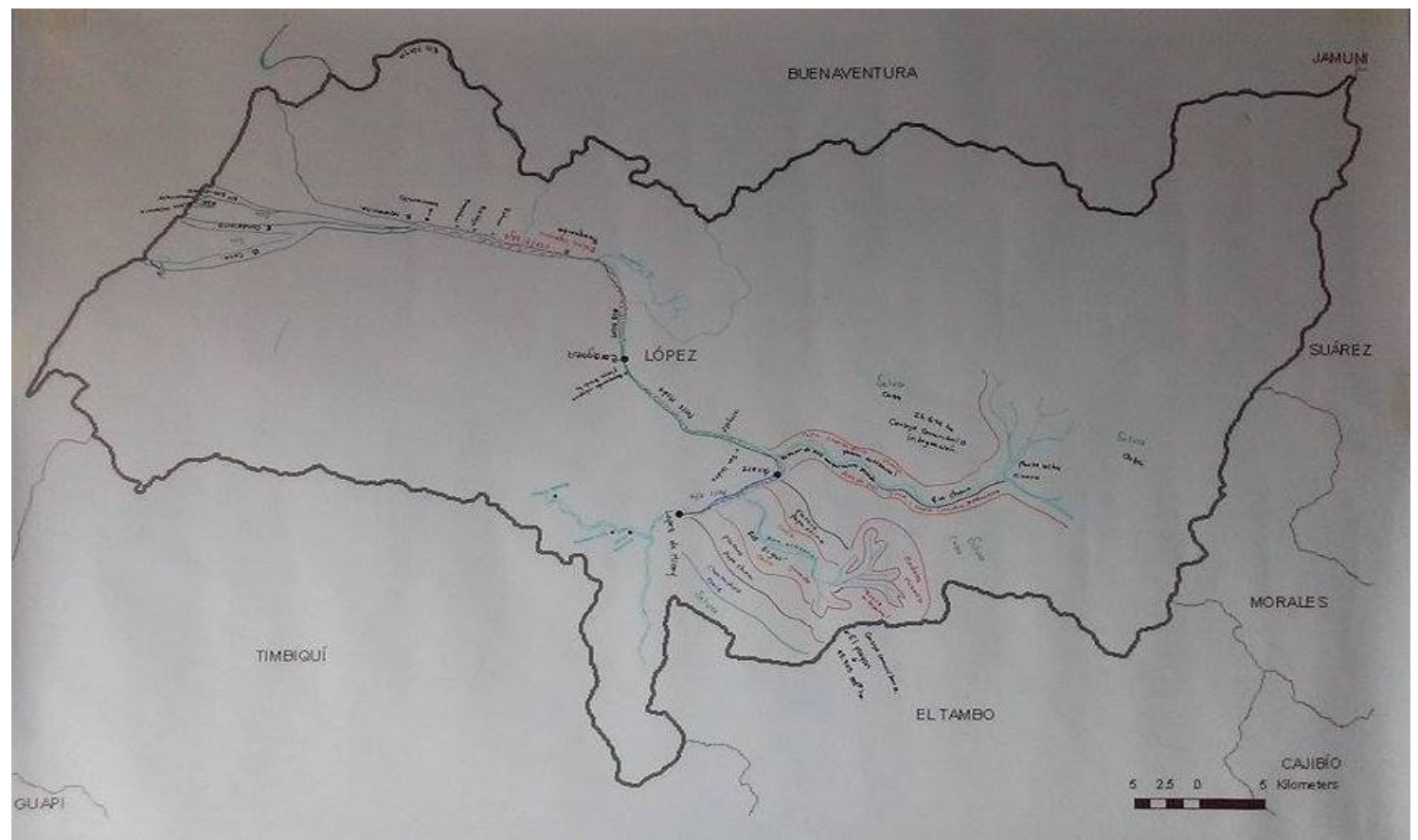

Fonte: Jesica W. Beltran CH e Cesar de David.

\section{CARTOGRAFIA SOCIAL NO MUNICÍPIO DE LÓPEZ DE MICAY.}

As comunidades negras no município de Lopez de Micay têm organizado seu território em unidades de paisagem, criando categorias espaciais que se caracterizam pelo uso e pelos significados que lhe outorgam, sendo estas unidades as que organizam no municipio, as quais são usadas no cotidiano para desenvolver as diferentes atividades sobre o território. Uma das características a destacar é o eixo formado pelo rio e pelo mar, sobre o qual se desenvolve a maior parte das atividades do Pacífico. Este elemento representa o espaço aquático (OSLENDER, 2008), é ali onde "se localizan los asentamientos en donde se construye las viviendas, se realiza la comunicación y los intercambios económicos, sociales y culturales. Así mismo, es el elemento primordial de adscripción territorial y de identidad" (ARIZA, V. et al, 1999: p 67). Também o espaço aquático é o referente para a criação de mitos, lendas, histórias e cânticos. O espaço aquático de Oslender (2008) é, portanto, um meio objetivo de organização do espaço e um meio subjetivo, fonte de memórias que vão narrando as histórias do Pacífico. 


\section{As unidades da Paisagem.}

$\mathrm{Na}$ cartografia desenhada pela comunidade, uns dos elementos gerais que foram identificados, foi à divisão do território em três unidades de paisagem. A figura 3 mostra um desenho da classificação geral dada ao território Micay, onde não só se mostram elementos de relevo e topografia, os quais são apreciáveis na realidade na medida em que se adentra ao município, desde a desembocadura até o Rio Micay no sentido norte-sul, mas também elementos relacionados ao ordenamento do espaço pelas comunidades negras que ali habitam.

Destacam-se os terrenos blandos ${ }^{3}$ : que correspondem a zonas planas pouco cuidadas, que tem influência da maré e, portanto, são terrenos inundáveis, os quais precisam de uma adequação prévia ao cultivo, como afirma Evaristo ao se referir a estes:

Esto se inunda al nivel del rio, cuando el rio aumenta mucho se inunda, y para sembrar hay que hacer unos drenajes para que pueda pasar el agua porque mantiene mucha agua, no tiene mucho nivel, son terrenos planos, entonces no tiene desnivel, entonces el agua siempre esta ahí para equilibrar, entonces la única manera de desequilibrarla es con los drenajes (Evaristo Viveros, fevereiro de 2014).

Como estes são terrenos que estão baixo a influencia da maré, é preciso conhecer a dinâmica da maré para o cultivo em espaços planos:

Más que todo en la parte baja, se trabaja con dos tipos de marea. Hay una marea que es baja y otra que es alta, acá nosotros la denominamos como marea de piedra o marea de puja. Las pujas no se siembra porque lo levanta el agua como es el coco y es la caña (...) entonces uno lo que hace es siembra en la marea de piedra, para cuando las mareas de puja llegue ya halla enraizado, para que la marea de puja no la levante (Evaristo Viveros, fevereiro de 2014).

De maneira que os terrenos blandos, não só vão distinguir aspectos da paisagem no território de Lopez de Micay, senão que vão diferenciar a forma de como se cultiva na parte baixa, media e alta do município, onde é preciso ter em conta principalmente aspectos como a maré. É importante destacar que os terrenos blandos são próprios do Conselho Comunitário Manglares.

Por outra parte os terrenos duros: são os que correspondem às colinas e montanhas, são terrenos não inundáveis e mais aptos para os cultivos, são terrenos que não precisam ser drenados, e que não requerem de muito trabalho e inversão Evaristo (2014) afirma que os terrenos duros são os melhores para semear:

\footnotetext{
O termo blandos faz referência a terrenos que apresentam baixa capacidade de suporte, devido a grande quantidade de agua
} que contem e por estar sob a influência da maré. 
"Para los árboles y los cultivos son tierras duras, hacia arriba (...) tierras duras de cordillera y tierras duras en la parte alta, porque ahí se invierte menos y los resultados son más" (Evaristo Viveros, fevereiro de 2014).

Entre os terrenos duros e os terrenos blandos se tem uma grande diferencia enquanto as técnicas de cultivo e também o custo deste:

"En las islas (parte baixa) se van muchos gastos y mucho tiempo,porque se sembró y cada tres meses hay que limpiar y en la parte alta a veces se va hasta los seis meses para limpiar" (David Ardila, fevereiro de 2014)

Figura 3: Ordenação do território de Lopez de Micay por unidades de paisagem.

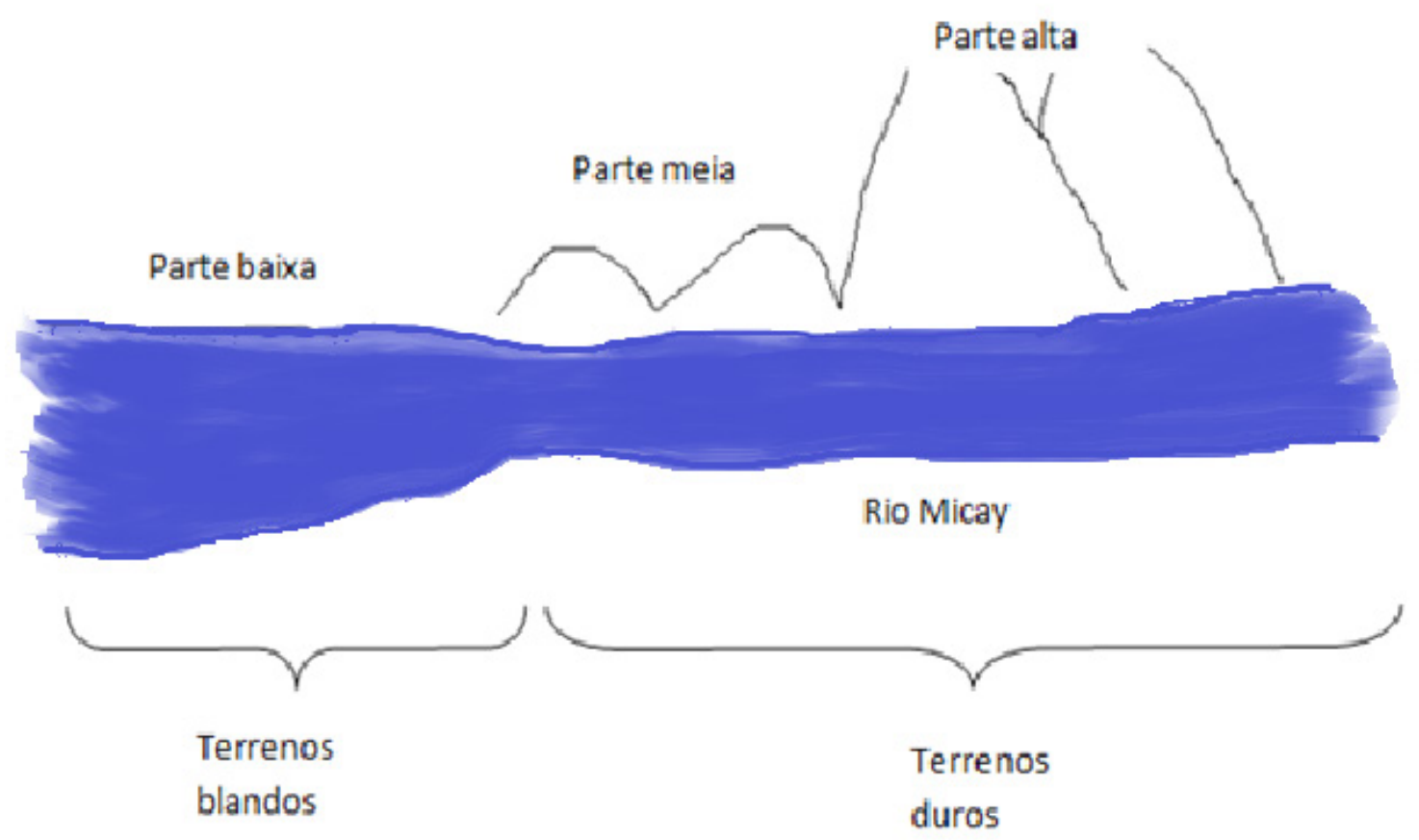

Organização: Jesica W. Beltran CHe Cesar de David

Estas categorias da paisagem, também são importantes quando se trata da medicina tradicional, ou dos rituais da comunidade para se conectar com o mundo dos mortos. A categoria parte alta cobra vital destaque, já que é nesta zona onde se encontram as plantas usadas para a medicina tradicional, em especial as plantas com grande poder curativo. Estas plantas são indispensáveis para a elaboração das botellas curadas, elemento fundamental na medicina tradicional da população negra do Micay. As botellas curadas, são feitas a base de plantas medicinais e se usam para curar qualquer tipo de doença, desde uma cólica até para curar a infertilidade da mulher, assim o relata o medico tradicional: 
(...) Bueno la albaca para una botella curada para la mujer, que no le de a luz, que no le sea fácil para tener familia, o si tiene mucho paspo cuando ya paren, que quedan lactando, que quedan medias malucas, entonces se le hace una botella curada,se le da cilantro en grano, ahí se le agrega a la botella canela, clavo, anis, alucema, mansanilla, altamisa, agenjo y la hierba de la mujer. (David Ardila, fevereiro de 2014).

Neste tipo de medicina as plantas cumprem um papel fundamental, pois a base da medicina tradicional são as plantas que geralmente se encontram nas partes altas, nas montanhas, o medico tradicional explica que se têm tipos de plantas que se tem caçar, são plantas que tem mistérios:

(...) hay una ruda de montaña que esa no se anda viendo, el amargo Andres es una planta como secreta, usted pasa así como tocando y pasa directo y no la ve, hay plantas que tiene su misterio. Esta montaña está muy llena de misterios de plantas muy buenas. Póngale cuidado del Ya-te-vi, que uno cuando entra en la montaña así no lo haya visto tiene que decir $Y a-t e-v i$, porque en caso que uno llegue a estar cerca del él se le tira a uno, lo agarra y le hace una herida (...) y se le va dañando el cuerpo por la herida. Con el Ya-te-vi se cura el mismo Ya-te-vi y el Ya-te-vi tiene muchas propiedades también" (David Ardila, fevereiro de 2014)

Outro aspecto da categoria de paisagem de montanha na medicina tradicional está relacionado a quem e como se pode entrar nela. O medico tradicional afirma que tanto homens como mulheres podem entrar na montanha para recolher plantas, mas há alguns estados em que a mulher e o homem não podem entrar na montanha:

\footnotetext{
"toda planta medicinal no se puede coger, entando usted en relaciones com su marido, estando la noche, haciendo el amor, no son épocas de coger las plantas (...) Si la quiere coger tiene que bañarse, todo cuerpo cuando se baña saca la impureza, la mujer cuando tiene la impureza mestrual tampoco puede coger plantas, no puede utilizar las cosas, (...) un hombre que tome una mujer con el periodo mestrual queda impuro, desde el amanecer hasta el oscurecer" (David Ardila, fevereiro de 2014)
}

Este tipo de aspectos lhe dá uma conotação à montanha como um lugar sagrado, é na montanha, nas partes altas, onde se desenvolve os mistérios, onde os espíritos da selva transitam como a Tunda ${ }^{4}$, são espaços indômitos, aqui cada segmento é apropriado, é significado, é classificado, tanto para as atividades de agricultura, pesca, e colheita. As categorias terreno blando, duro, de parte baixa, média, alta ou montanha são elementos que configuram o território negro, e é a partir de ali que se desenvolvem as diferentes atividades. O que todas estas categorias espaciais de representação refletem é o intimo contato que durante séculos as comunidades negras tem tido com os distintos elementos do meio natural que lhes rodea, permitindo dá-lhe uma ordem.

A Tunda para os negros do Pacifico representa o espírito da selva. 


\title{
Cultivos e lógicas de produção.
}

Os espaços de uso são unidades de análise do território a partir das classificações próprias das comunidades afrocolombianas, onde eles estabelecem espaços diferenciados que se relacionam com a terra e a água, dois elementos fundamentais para a produção de suas vidas (ARIZA, V. et al, 1999). Os sistemas tradicionais de produção são diversificados e estão sujeitos as condições físico-geográficas do município.

\begin{abstract}
Las caracteristicas básicas de estos sistemas productivos son: se fundamentan en el uso de la biodiversidad, tanto silvestre como domesticada, tiene una visión ecosistemica, combinan en el tiempo y en el espacio diversos sectores productivos como la agricultura, la minería artesanal, la extracción forestal, la horticultura, la caza la pesca, los servicios etc; están dirigidos primordialmente a preservar el sistema de seguridad alimentaria de la comunidad y no a la acumulación, dominan los policultivos, la unidad productiva es discontinua, los barbechos (montes biches) juegan un papel importante como proveedores de recursos biológicos y en la recuperación del suelo y bosques, los saberes productivos y tecnológicos se transmiten por tradición, incorporan el trabajo domestico y los sistemas de solidaridad como la mano vuelta y la minga (SANCHES \& LEAL apud ARIZA, V. et al, 1999, pg. 23).
\end{abstract}

A lógica do uso do solo nos espaços do Pacífico, no município de Lopez de Micay, está enraizada na reciprocidade entre a natureza e homem, pois os sistemas de cultivos, a presença da policultura, das práticas de mineração, da coleta de moluscos, da caça, da pesca, da extração de madeira são atividades que as comunidades têm praticado ao longo do tempo, em regime de complementar uma das outras. De maneira geral, alternam as atividades dependendo do tempo, comumente medido em relação as fases da lua (marés) e do espaço, como por exemplo, a atividade de caça, a qual se pratica nas partes altas de montanha ou a atividade de colheita de moluscos nas zonas de manguezais, nas quais se imprime as conotações de espaço (parte alta e baixa), já mencionadas no transcurso desse artigo.

Em quanto a rotação de cultivos, o Pacifico se caracteriza pelo que se chama tumba e pudre, a qual West (2000) descreve da seguinte forma:

Para la mayoría de los trópicos del mundo la agricultura de tumba y quema, lo que implica el uso del fuego para la limpieza de los terrenos. Sin embargo en la mayoría de las tierras bajas del Pacifico la alta pluviosidad y la falta de una temporada verdaderamente seca impide el uso efectivo de fuego. En su lugar se utiliza un sistema peculiar, que podríamos llamar de tumba y pudre, cuyo origen es probablemente indígena. Las semillas se riegan al voleo y los rizomas e esquejes se siembran en un terreno que aún no ha sido limpiado. Luego se tumba el monte y el rápido pudrimiento de la vegetación forma una capa de 'mulch' a través de la cual se ven aparecer los brotes de las semillas y de los esquejes en espacio de una semana a diez días (WEST, 2000, pg. 65-66). 
Este tipo de sistema de cultivo praticado tanto pelas comunidades indígenas como pelas comunidades negras são considerados adaptativos, resultam de um processo histórico de conhecimento e uso da floresta úmida tropical (ARIZA, V. et al, 1999).

Convém apontar que o sistema de cultivo no Pacífico colombiano adquire uma lógica de produção específica da floresta tropical. Margarita Serje (2011) aponta que este tipo de produção não vai direcionado ao mercado, senão que se orienta por outras lógicas, as quais fundamentam-se na reciprocidade entre homem-meio, em que as florestas são, em parte, um produto do trabalho entre as comunidades que ali habitam. A configuração desses tipos de cultivos apresentam uma aparência caótica, a partir da leitura que se faz na tradição européia, a qual é vista como 'monte'5 (SERJE, 2011:103), ou seja, como áreas que ainda não foram aproveitadas e trabalhadas. A este respeito Serje argumenta:

"La Selva es un producto de las sociedades que viven en ella; la etnología y la arqueología han ilustrado ampliamente el proceso de producción del bosque en la Amazonia y han mostrado como en buena parte, su diversidad es el resultado de la intervención humana" (SERJE, 2011:103). Portanto, a floresta é considerada não como um espaço que se mantém inalterado, mas, pelo contrário, um espaço que se transforma constantemente, nas palavras de Serje a floresta é "el producto social de las sociedades que conviven con ella" (2011:104).

Desde a visão ocidental, a floresta, se pensa como um espaço que deve ser conservado e protegido, argumentos que nascem do discurso ambientalista na década de 1960 e 1970, o qual evidencia que não se pode pensar em outras lógicas de produção que não estejam ligadas à monocultura em grandes extensões de terra ou ao uso de agroquímicos, inviabilizando, assim, outras lógicas (comunitárias) de uso e controle do espaço rural.

\section{Percepção espacial do espaço Rural.}

As comunidades do município do Micay têm adotado algumas representações espaciais que classificam o espaço rural, as quais se geram a partir de componentes simbólicos que se tem criado ao longo de sua convivência com a floresta tropical há mais de três séculos, e que representam seu espaço de vida. A figura 4 mostra um esquema de classificação do espaço desde a unidade mais elementar que é a casa.

Quando Margarita Serje, fala de 'monte’ se refere a áreas não trabalhadas, não cultivadas, que não tem uma ordem. 


\section{Figura 4: Classificação do espaço rural no território negro do Pacifico colombiano.}

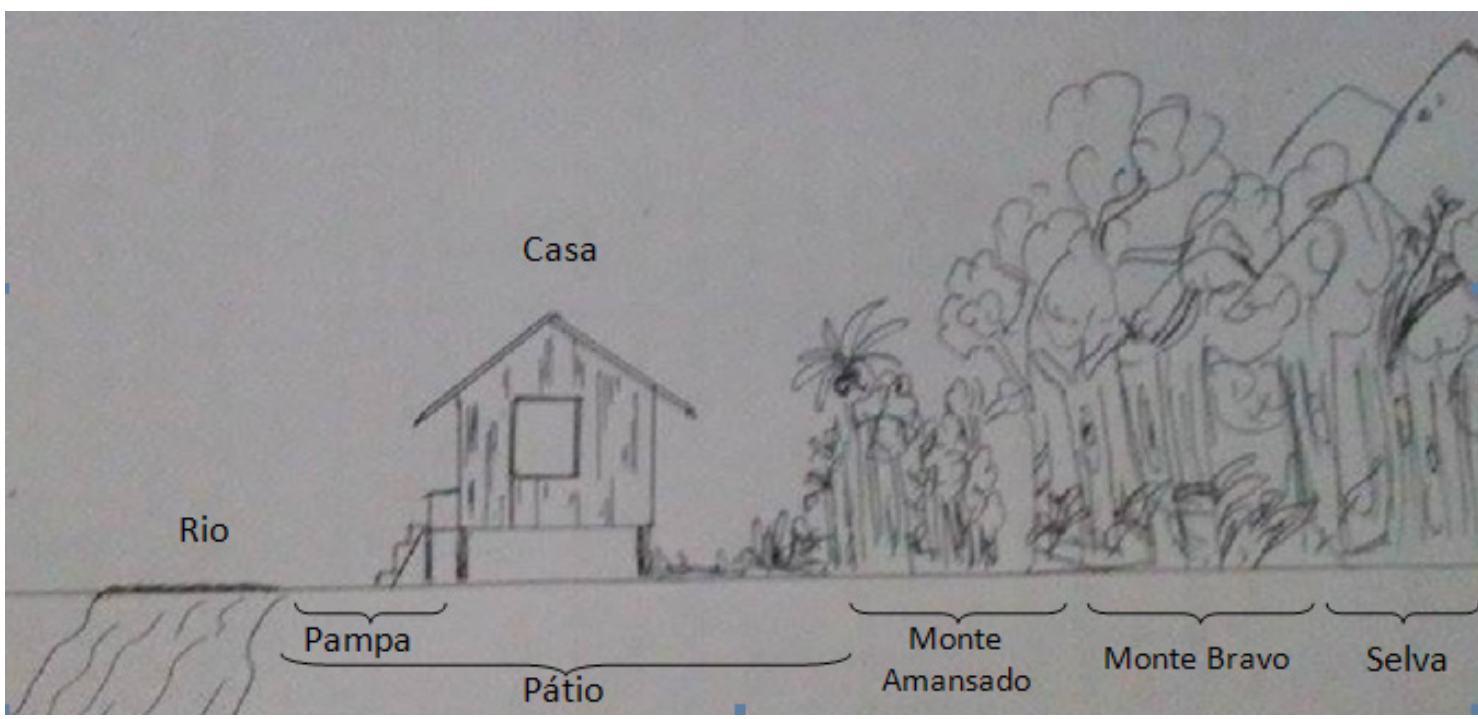

Organização: Jesica W. Beltran CHe Cesar de David

A partir da casa, que é a unidade menor em termos de extensão, se classifica os outros espaços, Antonio Torres ecólogo e membro da comunidade explica cada um destes elementos:

Nosotros tenemos una vaina que se llama, lo que está alrededor de la casa nosotros le damos nombre de patio, lo que está entre la casa y el monte allá, le llamamos bosque amansado (...) que es el bosque que queda entre lo que la gente roza y la selva, y lo que está más allá para llegar a la selva se le da el nombre de monte bravo(...) y lo que está más allá, eso ya le llamamos zona selvática, selva (Antonio Torres fevereiro de 2014)

A pampa, o pátio, o monte amansado, o monte bravo e a selva, são representações elaboradas pelas comunidades negras no Pacífico colombiano. Em um estudo feito no departamento do Chocó, ao norte do Pacífico colombiano, pelo antropólogo Eduardo Restrepo (1996) se encontraram classificações similares a estas, onde a categoria monte amansado faz referencia aos espaços domesticados, neste caso do monte amansado para o rio representaria os espaços domesticados, e do monte bravo para a selva em sentido contrário, representa o desconhecido, o não domesticado, onde se encontram os espíritos; outro significado que se lhe outorgam a área de monte bravo é como zonas de reserva, pois "son áreas que se guardan para el mantenimiento de las aguas, de las especies, de los espíritus y para épocas de grandes fiestas, o de crisis alimentarias" (ARIZA, V. et al, 1999: p 85).

Outro elemento fundamental de representação é o rio, pois a organização do espaço rural por parte das comunidades negras está orientada pelas redes de drenagens. São esses os eixos centrais de orientação. Já o destaca Peralta (2012) que o sentido de orientação é guiada pelos rios, o sentido arriba e abajo "siguiendo el fluir de la corriente fluvial, 
el arriba está representado en una dirección que concurre hacia las cabeceras de los ríos [à montante] y el abajo está indicando que el viajero se va a dirigir hacia puntos que están referenciados en el sentido de sus desembocaduras [à jusante]" (PERALTA, 2012:120), em sentido contrário se usa a orientação arriba/abajo quando se fala da localização do viajante no Oceano Pacífico. Abundio Campaz, narra sua história quando ficou perdido no mar, a qual serve para entender o sentido de orientação no mar:

A mí me paso una vez cuando estaba pescando por Tumaco (departamento de Nariño), cuando estaba pescando tortuga, son las que le dicen caguama, eso se pescaba y eso era uno a vender a Ecuador, se quemaba uno quince galones de gasolina, sin brújula, sin nada. Estaba metido en el mar, yo le cuento que una vez salimos, hermano y se vino un viento de abajo, era un viento de norte con el sureste nos ponía a un lado, y eran las tres de la tarde y viajábamos tres, yo dije muchachos vámonos, dele maquina dele máquina, no se mira tierra, estábamos perdidos, nos quedamos sin agua, lo peor de ser humano es quedarse sin agua, comenzaron a tomar agua salada. y yo dije: el primero que se muera lo boto al agua, porque yo no voy a cargar con muerto aquí, entonces mis niñas anochecimos en el mar, amanecimos en el mar, volvimos a amanecer en el mar, tres días, tres noches, yo no me iba a morir de hambre, llevábamos eso lleno de tortugas, yo aquí como tortugas vivas, iyo me las como! (...) habíamos cazado pescado y chau chau chau, me toco comer pescado crudo, y a los tres, cuatro días una lancha, ya estaba la noticias de unos perdidos en el Ecuador, Colombia, en toda parte, y nos dijeron ihey! ustedes eran los perdidos, nos dieron gasolina, galletas, gaseosa, ¡nos estaban buscando!, y adivine donde estábamos, jen el Ecuador!, llegamos allá vendimos las tortugas...tres días perdidos por Tumaco. (Abundio Campaz, fevereiro de 2014)

$\mathrm{Na}$ historia deste pescador, se pode ver que a orientação dos ventos, vento de $a b a i$ $x o$, se refere aos ventos que vem do norte, e o arriba, no caso se refere aos ventos do sudeste. De forma que o sentido de localização das comunidades negras vai em via contraria a localização cartográfica, quanto o norte é, para elas, o abajo, e o sul é o arriba. Estas representações ganham vital importância em termos de controle territorial e delimitação, em que as classificações espaciais mostradas dão uma dimensão do controle do espaço, da mesma forma que as categorias de zona baixa, média e alta. É a partir do conhecimento destas categorias que se localizam os diferentes espaços para realizar as diferentes praticas de agricultura, caça, extração e coleta, como também para definir as fronteiras, no caso do monte bravo e a floresta, pois estes são espaços do "conhecimento privilegiado" (PERALTA, 2012, pg. 125), "Aquí el hombre no es protagonista de la relación naturaliza/sociedad y, por ende, está obligado a pensar con mayor detenimiento los términos de interacción con el entorno biofísico" (PERALTA, 2012, pg. 125). O medico tradicional do município de Lopez, David Ardila, explicou que qual quer pessoa pode entrar no monte bravo, mas para entrar é preciso estar limpo, no caso da mulher, ela não deve estar com o período menstrual, e nos homens, estes não podem ter tido relações sexuais; desta maneira se expõem menos as coisas que são desconhecidas pelo homem, aponta David, que 
o monte bravo também é o lugar dos espíritos. Ele narra em muitas de suas historias seus encontros com a tundra, como ela já fez que ele se perdesse na floresta. Assim como esta, há muitas outras histórias de pescadores que não vão pescar até muito tarde da noite ou não pescam em águas desconhecidas, pois ali habitam seres de outros universos, os quais fazem parte da cosmologia das comunidades negras do Pacifico colombiano.

Por outro lado Lynch já em 1978, ao estudar o conceito de percepção e como se cria uma imagem urbana, nos tem ajudado a compreender que através da estrutura, identidade e significado, estas entendidas como o grau no qual o espaço pode ser percebido, mentalmente diferenciado e estruturado, no tempo e no espaço por quem o habita, e ao mesmo tempo como estas estruturas mentais criadas se conectam com valores e conceitos dos mesmos, criam uma imagem nítida do espaço. Dessa forma o ajuste entre o entorno, nossas capacidades mentais e sensoriais e nossas construções culturais permitem a criação e organização de uma imagem do espaço rural no Pacifico Caucano.

Neste sentido se pode entender como mediante a percepção espacial as comunidades negras tem estruturado e classificado o espaço rural desde os âmbitos mais conhecidos: a casa, pampa, pátio e monte amansado, até alcançar os confins das terras ou das aguas: o monte bravo e a selva, que são os lugares mais afastados (PERALTA 2012), os quais contém uma carga simbólica e de significados que explicam o uso e a estrutura da floresta tropical nas comunidades afrodescendentes do Pacífico colombiano.

\section{Espaço Aquático.}

Oslender (2008), por sua vez, compreende a região Pacífica, como um "espaço aquático", ao afirmar que as "relaciones sociales cotidianas entre las comunidades negras como condicionadas profundamente por diversos elementos acuaticos del entorno particular del Pacifico" (pg. 24), entendido este principalmente a partir do sentido de pertença ao rio, sendo esta, a territorialidade que estas comunidades tem construído ao longo dos séculos, pois por meio do rio se ordena o território e se dispõe espacialmente aspetos fundamentais da sua vida (OSLENDER, 2008). Um exemplo claro da influência do espaço aquático nas comunidades negras se reflete em elementos significativos de ordenação do território a partir do rio, ja que a divisao politico administrativa das comunidades negras estao dadas pelo que se tem chamado de conselhos comunitarios, os quais tem como eixo principal o rio que o cruza, sendo este também um elemento fundamental para a construção de identidades e de apropriação do espaço aquático: 


\begin{abstract}
Con espacio acuático quiero indicar los modos en que los elementos acuáticos como la constante presencia física o simbólica del mar, las intricadas redes fluviales, las quebradas, las cascadas, los manglares, los elevados niveles de precipitación, las importantes variaciones en las mareas y frecuentes inundaciones a gran escala- han influenciado y dado forma de manera sustancial a los patrones de vida cotidiana en la región y la manera como se han desarrollado en la series especificas a las cuencas de los ríos del Pacifico(...) El espacio acuático, entendido como localidad, enmarca los escenarios formales e informales y las relaciones sociales que las comunidades negras han construido con el tempo en sus respuestas adaptativas al entorno acuático y la manera como han tomado forma en el espacio, según una lógica acuática, por ejemplo, en los patrones de poblamiento a lo largo de los ríos (OSLENDER, 2008, pg.133)
\end{abstract}

Oslender também destaca que as comunidades negras não só se diferenciam etnicamente das outras comunidades étnicas presentes na Colômbia, como também se distinguem como movimento negro enquanto tem uma especificidade espacial diferenciada de outros movimentos negros na Colômbia e em outros lugares (OSLENDER, 2008, pg.31). O espaço aquático que se refere o autor vai além da ordenação espacial do território negro através dos rios, mas, este, esta presente em todos os âmbitos, culturais, simbólicos, de praticas agrícolas e luta como movimento negro o qual o faz particular, único.

Portanto, este espaço diferenciado pode ser entendido como contra-espaço, segundo os postulados teóricos da obra de Lefebvre (2006): A produção do espaço. "Na acepção ampla, os homens enquanto seres sociais produzem sua vida, sua história, sua consciência, seu mundo. Nada há na história e na sociedade que não seja adquirido e produzido. A "natureza", ela mesma, tal como se apresenta na vida social aos órgãos dos sentidos, foi modificada, portanto, produzida" (LEFEBVRE, 2006: 106). A partir desta visão Lefebvre define três formas de produção do espaço: a.) práticas espaciais, b.) representações do espaço e, c.) espaço representacional, Oslender (2008) para conceituar o espaço aquático as define baseado na teoria de Lefebvre da seguinte forma:

a. As práticas espaciais são as formas nas quais as pessoas geram, usam e percebem o espaço. As quais estão intimamente ligadas à vida cotidiana, às memórias e aos resíduos de vida mais antigas e diferentes, pelo qual leva a resistir à colonização de espaços mais concretos ${ }^{6}$.

b. A representação do espaço faz referência aos espaços concebidos por uma lógica particular, de saberes técnicos e racionais, este faz referência ao saber científico, este representado no capitalismo contemporâneo, onde a lei do mercado como lógica dominante conduz a uma maior mercantilização da vida social.

\footnotetext{
Os espaços mais concretos que faz referência Oslender (2008), é baseado no pensamento de Lefevre, o qual o representa o
} espaço acabado, definido pela ciência. 
c. Espaço representacional, estes são formas menos formais e locais de conhecimento, que são dinâmicas e simbólicas e saturadas de significado.

Lefebvre (2006) indica que cada sociedade produz seu espaço, no sentido conceitual desta trilogia, o qual se deve olhar de forma interligada e interdependente (OSLENDER, 2010). Neste sentido, o espaço aquático representa um espaço de resistência. "En efecto, el lugar del Pacifico colombiano se convierte en el centro de la lucha por las representaciones del espacio" (OSLENDER, 2008:63), de forma que essa luta se reflete nas formas como as comunidades negras do pacífico percebem e representam o espaço frente ao poder hegemônico de mapear, o qual se tem reinventado com os SIG, mas que não tem implicado, necessariamente, a eliminação das formas de representações espaciais no Pacífico colombiano, já que, pelo contrário, ao serem estas tecnologias mais acessíveis tem possibilitado vitórias quanto à luta pela terra destas comunidades frente ao Estado.

O espaço aquático por tanto, se enquadra na trialetica do espaço de Lefebvre de forma que o rio representa o cenário físico do qual se dão as interações sociais cotidianas e que se baseia na articulação específica destas interações (OSLENDER, 2008). É assim, o território percebido e representado que dá lugar ao espaço aquático, o qual é físico, simbólico e político (ou seja, um espaço de luta).

Assim, para Oslender o espaço aquático transcorre desde o subjetivo (as relações que as comunidades negras estabelecem com o elemento água e o sentido de pertencer a um determinado ambiente aquático) e o objetivo (como a localização e os padrões de povoamento sobre as ribeiras dos rios). E também é o marco explicativo do lugar onde se geram "los discursos y prácticas del movimiento social de comunidades negras" (OSLENDER, 2008:134). Assim o físico, o simbólico e o político se enquadram nos postulados de Lefebvre (2006), numa realidade particular, a do Pacífico Colombiano.

\section{Territorios de Fronteira.}

A historiadora Margarita Serje (2011), identifica na Colômbia o que tem chamado de Territórios de Fronteira. Segundo a autora a fronteira deve ser entendida "como concepto espacial colonial, apunta entonces a la existencia de líneas fijas inequívocas, que perfilan perímetros de carácter excluyente. Esta noción no se ha visto aplicada únicamente a los limites nacionales sino también a los limites culturales, llegando a asociar territorios étnicos con unidades biogeográficas"(SERJE, 2011, pg.148), como é o caso das comunidades negras na região Pacífica. É importante destacar que a noção espacial de fronteira está enraizada segundo as noções tradicionais europeias de compressão da história da espacialidade, o que quer dizer que segue uma lógica de oposição entre natureza e cultura 
(SERJE, 2011, pg.148), o que lhe confere carácter histórico, para a compreensão do espaço rural de floresta úmida tropical, o qual foi concebido desde os tempos coloniais como:

El conjunto de nociones asociadas al concepto occidental de frontera se vio condensado finalmente en la demarcación espacial de las zonas civilizadas apropiadas por la administración colonial, y las salvajes, tras las que se expresan la separación de un mundo amenazante sobre el que se proyectan por igual sueños y pesadillas. Muchas de estas quedaron inmortalizadas con divisiones político administrativas, como la separación del piedemonte llanero de los altiplanos cordilleranos, dividiendo en 'departamentos' y e 'unidades biogeográficas una región que evidencia una interacción continua desde épocas pre coloniales (SERJE, 2011, pg.151).

De maneira que as categorias selvagens - civilizado vão determinar o adentro e fora do novo mundo. O selvagem representado na floresta vai representar o oposto a civilização, “y más tarde a la razón: representa la oscuridad de lo ininteligible frente a la claridad de la ciencia y de la técnica, de la agricultura, la anarquía y el caos frente al orden de racionalidad, lo circular, femenino y dislocado frente a lo patriarcal, recto y ortogonal" (SERJE, 2011, pg.123).

A ordenação do território colombiano a partir desta interpretação colonial vai ser a que irá designar esses espaços "selvagem" de floresta, como terrenos baldios e devolutos, não reconhecendo aos "selvagens" nenhuma propriedade sobre a terra as quais cultivam, caçam, pescam e habitam, pois na lógica do modelo de agricultura hegemônica estas terras não são cultivadas, não sofreram a intervenção do homem e, muito menos, possuem articulação com o mercado. Essa situação de fronteira, então, condiciona os espaços de floresta à exclusão e ao esquecimento, uma vez que esses territórios não encontram-se integrados às lógicas produtivas do mundo euro-andino, onde a articulação à rede de rodovias, à circulação de mercadoria e o controle militar, pautam o nível de desenvolvimento, convertendo em periferias, "modernizaciones incompletas, o naciones en construcción, o como países en vías de desarrollo" (SERJE, 2011:21) na Colômbia e regiões como o Pacífico.

El mito-concepto de frontera sintetiza el conjunto de apelativos históricos con lo que estos espacios han sido conceptualizados y categorizados con fines, baldíos, territorios nacionales, y los recubre con el 'efecto montesquieu'. En esa medida, pone en marcha el conjunto de estas estrategias territoriales, legitimando un punto de vista: el punto de vista urbano, modernizante y el colonial de las elites, en el que se reformula de manera velada la distinción colonial básica entre lo civilizado y lo salvaje (SERJE, 2011, pg.173). 
Nesta lógica a agricultura praticada em espaços de floresta como o Pacifico, são invisíveis e ignoradas a luz das ciências agronómicas baseadas em outros princípios (SERJE, 20011), pois a produção no Pacifico e no município de Lopez de Micay especificamente, não se dirige ao mercado moderno. Serje (2011), explica que este tipo de agricultura de floresta (baseando-se no modo de cultivo na Amazônia), se orienta a:

La reprocidad o la redistribución, por otra parte, su configuración busca el aprovechamiento de la luz solar perpendicular de la zona ecuatorial (...) Por ello, su estructura es vertical, alrededor de agrupaciones puntuales muchas veces organizadas en espiral, a la manera de una escalera de caracol, creando varios estratos o niveles y combinando por tanto, una gran diversidad de especies" (SERJE, 2011, pg.101)

Da mesma forma no município de Lopez de Micay os modos de cultivos, de caça, de coleta e de pesca, responde a lógicas diferenciadas, de conhecimento da floresta úmida tropical e de uma relação homem-natureza, conforme descreve Serje (2011, pg 104) "todo ello va mucho más allá del aprovechamiento pasivo de la abundancia del medio, que es como coloquialmente se entiende el concepto de caza y recolección, es decir como opuesto a la cultura”.

Esta lógica colonial herdada, então, considera a floresta em si, por fora das ciências rurais e agrarias, e portanto, apresenta outro tipo de conotação, não agraria/rural, na qual é concebida como virgem, como espaço de reserva e proteção, "o pulmão do mundo", ou como um lugar de recursos ambientais a serem explorados. Ao contrário deste discurso, a floresta é "el producto social de las sociedades que conviven con ellas, sin embargo, la cultura, tanto en el sentido del cuidado y producción de la tierra como en el sentido de organización social de los grupos de selva ha sido sistemáticamente organizada" (SERJE, 2011:104).

No município de Lopez de Micay a floresta tem uma organização que tem como eixo central os rios, e assim mesmo ela é usada, trabalhada, apropriada e simbolizada. A configuração destes espaço de floresta, longe de ser os espaços civilizados segundo a perspectiva colonial, representam na atualidade espaços de resistência, que tem possibilitado "el desarrollo de sociedades de resistencia, relativamente autónomas, producto de nuevas alianzas y configuraciones" (SERJE, 2011:16). Assim, essa situação de fronteira ao mesmo tempo que invisibliliza e condena o desenvolvimento, também possibilita a criação de outras formas, de relações particulares do homem-natureza, relação esquecida pelo homem moderno.

Entretanto, o Estado colombiano em seu propósito por incorporar os territórios de fronteira ao geo-corpo do estado-nação (SERJE, 2011), por meio da exploração dos recursos naturais e a implantação de um modelo agrário direcionado a monocultura do óleo de palma, como é o caso do Pacifico; tem causado um conflito pela terra e pelo território. Es- 
sa mesma terra que em tempos coloniais representava as zonas selvagem, incivilizadas, de solos inférteis, baldias etc., que hoje por suas características biofísicas e a oferta ambiental, se torna visível ante o capital e o mercado internacional para sua exploração, o qual tem gerado conflitos e violência, caracterizando-as como zonas vermelhas, onde predomina a lei do mais forte (SERJE, 2011). Isso mostra que estas zonas fogem do controle estatal e do projeto nacional hegemônico, por serem espaços que "ainda" não foram incorporados à sua ordem (SERJE, 2011). Essa situação permite a alguns autores afirmarem que na Colômbia há muito território e pouco Estado:

\begin{abstract}
Estas ricas e inhóspitas regiones se han convertido a lo largo de la historia en el lugar de la historia en el lugar de refugio de poblaciones sobre las que se han operado un proceso de doble inversión, gracias al cual solo se las reconoce, o como potencial de conflicto, de ilegalidad y desafío, o como instrumento para el logro de los ideales de la sociedad urbana, ilustrada y sus intereses. O bien como sociedades cuyo potencial de violencia pone en peligro cualquier posibilidad de imprimir el orden, cuyos designios, por estar más allá de su comprensión, deben acatar sin cuestionar ni resistir. Evidentemente, el designo lo erigen quienes poseen la iluminación de la ciencia, de la técnica, de la economía: las clases urbana ilustrada, el 'pueblo de poetas' que se atribuye así mismo la herencia de los ojos imperiales. El doble proceso de inversión pone en evidencia que la diferencia es producto de la relación de dominación (y no al contrario). Se trata de un proceso que define las identidades la naturaleza de los sujetos, en función de una lógica que reivindica un punto de vista particular que niega a las poblaciones su propia continuidad geográfica e histórica y las inserta en lo real ubicándolas dentro de un contexto en particular: el de la empresa fundacional de la nación y del sistema de conocimiento que ha privilegiado para lograr la integración de una economía nacional articuladas al sistema global moderno, que, como señala Wallestein surge con la incorporación de las Américas al circuito comercial europeo en el siglo XVI” (SERJE,2011, pg. 259)
\end{abstract}

O município de Lopez de Micay é considerado um território de fronteira, por suas características biofísicas de floresta húmida tropical, pela violência armada, pela pobreza e invisibilidade, que o tem tornado na periferia da periferia na Colômbia. Esta invisibilidade ao mesmo tempo possibilitou a organização das comunidades negras, como grupo de resistência, que não apenas luta para preservar a natureza, senão que torna a natureza, a floresta húmida tropical como elemento essencial da reafirmação de sua cultura.

\title{
A FLORESTA TROPICAL UMA CATEGORIA ESPACIAL DO ESPAÇO RURAL.
}

O espaço rural desde a visão do governo colombiano é considerado como um espaço tradicional da agricultura, que não leva em conta as complexidades do território colombiano. Esta visão tradicional se expressa nas estatísticas nacionais: 
El DANE (Departamento Administrativo Nacional de Estadística) tiene tres grandes categorías para reflejar los tamaños de las aglomeraciones poblacionales: "cabecera", "centro poblado" y "rural disperso". Los centros poblados y el rural disperso conforman la categoría "resto", la cual ha sido tradicionalmente identificada como "lo rural", mientras que la cabecera se haya identificada como "lo urbano". Este es el origen de la conocida aseveración de que el 75\% de la población del país es urbana, mientras que el 25\% restante rural (PNUD, 2011, pg.53).

Esta relação cabecera - resto distorce a realidade do campo e dos espaços rurais na Colômbia e no Pacifico caucano, já que a diferenciação entre rural e urbano se da a partir do numero de habitantes no censo de população que faz o DANE, sem considerar outros aspectos específicos de um espaço e de outro.

Por outro lado, o rural também é considerado a partir da perspectiva de integração com o mercado, conforme o evidencia o Informe Nacional de Desenvolvimento Humano de 2011-PNUD, ao propor os índices de ruralidade, que mostram a inserção aos espaços de mercado através da distância e rede de rodovias. Assim, as zonas que tem índices de ruralidade baixos são os que tem muito pouca articulação com o mercado e as zonas urbanas, como é o caso do Pacifico caucano. De maneira que o rural continua a ser definido a partir de critérios econômicos, mensurado através de sua inserção ao mercado.

Essas formas de conceber a ruralidade na Colômbia, não são suficientes para alcançar a compreensão da ruralidade no Pacifico, pois este rural que aponta o PNDU e o DA$\mathrm{NE}$, seguem as mesmas lógicas do planejamento, do capital e do mercado, próprias do saber ocidental, que definem o espaço rural a partir de seus elementos objetivos, ignorando que a subjetividade também cria e re-cria o rural.

O que chamarei o espaço rural realizado é aquele que considera o espaço rural em sua totalidade, em que o físico, o social e o simbólico é considerado para interpretar o espaço rural. Assim a floresta húmida tropical corresponde a uma categoria espacial do rural realizado, em que as construções simbólicas tem um papel importante na construção e ordenação do espaço rural, Mormont (1996) explica:

Nesses termos, se considera que a noção de rural corresponde a construções simbólicas pertencentes a diferentes universos culturais que lhes atribuem significados distintos. Através dessa classificação, é possível compreender a sociedade e construir uma representação do mundo social em torno do tempo e do espaço (Apud CARNEIRO, 2008, pg. 30).

\footnotetext{
Define-se o "rural realizado" fazendo referencia ao que Bourdieu (1993), tem chamado como "categoria realizada", e que Carneiro (2008) define como "categoria de pensamento, no qual "uma categoria de pensamento (político-ideológica e relacional) do mundo social” que define identidades e sustenta reivindicações” (30).
} 
Nesse sentido a ruralidade da costa pacífica, representa-se pela floresta úmida tropical, categoria de um espaço rural diferenciado, que se pode interpretar em três aspectos:

O primeiro aspecto considera a floresta úmida tropical como espaço concreto, o qual não se diferencia a partir de categorias dicotômicas rural-urbano, pois na teoria já abordada estas duas categorias existem quando se diferencia uma da outra. O Pacífico pelo contrário é considerado um espaço contínuo, onde as comunidades negras tem manejado historicamente este espaço com o "uso de estrategias alternativas de subsistencia en diferentes áreas naturales de acuerdo al ciclo anual complementados con su trabajo en los centros urbanos" (VARGAS; FERRO apud ARIZA, V. et al, 1999, pg. 76). Estes centros urbanos chamados de centros povoados no município de Lopez de Micay, só tem essa conotação de "urbano", porque considera a concentração de habitantes em um mesmo lugar, assim o explica Antonio habitante de Lopez de Micay: "la gente ve como urbano lo que deberia ser rural, para poder aumentar el recurso de la poblacion en la parte de Lopez de Micay que son como dos mil habitantes no mas, porque Lopez de Micay es eminentemente rural"(Antônio, fevereiro de 2014). De forma que ao considerar centro urbano os povoados rurais que concentram maior população, indiretamente também se aumentam os recursos que o governo disponibiliza para cada município.

Cabe destacar que a noção de centro povoado difere das categorias de ordenamento que o Estado tem estabelecido para diferenciar áreas rurais e urbanas, as quais correspondem a resto e cabecera, respectivamente. No município de Lopez de Micay se tem optado por definir os centros povoados como espaços que não tem população dispersa. Antônio explica também que estes centros povoados são considerados centros na medida em que, além das casas estarem unidas, estes tem a presença da escola, ou a igreja, ou em alguns casos a presença do posto de saúde, ou seja, todo centro povoado nas ribeiras dos rios em Lopez de Micay tem que ter a presença de alguma instituição, a qual projeta de alguma forma a ordem, Antônio também aponta que depois dos centros povoados se encontram comunidades rurais dispersas também assentadas ao longo do rio.

Esta forma de organização em centos povoados e comunidades rurais dispersas, também mostram a continuidade do espaço rural, em quanto sua organização espacial esta definida pela aglomeração de população e não por características que define rural ou urbano. A continuidade também se reflete na ordenação do território por unidades de paisagem, ou na classificação do território negro, classificações que tem uma conotação mais simbólica do espaço rural, pois nestas se evidenciam a relação e conhecimento que a população tem com a floresta úmida tropical. 
O segundo elemento diferenciador é a marcante conotação simbólica que os habitantes atribuem à floresta. Aqui a ruralidade é compreendida a partir do espaço vivido, pleno de significações, de mitos e de histórias locais, nesse sentido a floresta é concebida como o habitat onde se vive e não a natureza a ser explorada (OSLENDER, 2008). Portanto, é o poder simbólico (Bourdieu, 1989), que as comunidades negras exercem sobre este espaço rural, que permite ordená-lo, classificá-lo e dominá-lo. A esse respeito Bourdieu (1989) aponta: "Os sistemas simbólicos, como instrumento de conhecimento, só podem exercer um poder estruturante porque são estruturados. O poder simbólico é um poder de construção da realidade que tende a estabelecer uma ordem" (pg. 9). Nesse sentido, a população negra do município de Lopez de Micay tem ordenado a floresta a partir de sua relação íntima com a floresta, o que permite classificá-la desde o elemento básico, a casa e o rio, da qual se parte para classificar a pampa, o pátio, o monte amansado, o monte bravo. No caso do rio como eixo espacial, se parte dele para classificar as unidades de paisagem: parte baixa, média e alta, e os terrenos duros e blandos. São estes elementos simbólicos que os afrodescendentes têm criado a partir de sua cosmovisão para ordenar o espaço. A ese respeito German Primera (2005), tem proposto a termo cosmoterritorialidade:

La vivencia del territorio también es una cosmovisión que entreteje significados vinculantes entre las personas y la metáfora del arraigo: un sentido para el grupo, la comunidad, la vida productiva, la vida recreativa. Ser parte del rio y al mismo tiempo sentir como propio este entorno significado a través del rio. Los afrocolombianos habitan ese lugar rural a nivel físico y simbólico, erigiéndolo como su patrimonio natural más importante, referente de identidad, así como la vida construida en sus riberas ha generado conocimientos propios, generadores de tradiciones de vida básicas para la existencia en ese lugar (apud OCAMPO et al. 2013, pg.55).

Na mesma direção, o terceiro aspecto se orienta a explicar a floresta como um elemento de identidade, que transcende as categorias de urbano/rural, cabecera/resto, na qual se tem uma apropriação pelo espaço principalmente pelos rios, o referente mais importante para os negros do Pacifico.

O espaço aquático (OSLENDER, 2006), então, tem um papel fundamental na construção de identidade, já que é o fator de identificação no Pacifico:

Una parte de esa naturaleza, de ese paisaje, resulta fundante en la vida de los afrocolombianos, en el lugar al que pertenecen y del cual se siente originarios (...) el rio es la referencia más inmediata para un afro; cuando habla de sus orígenes no se refieren a un pueblo o vereda en particular, menciona al rio correspondiente en cuyas orillas viven (...) en el rio se desarrolla la vida de los afrocolombianos, su cotidianidad; es el lugar donde cocinan, se bañan, se lavan y se recrean las personas, espacio donde se transita y se consigue el alimento (OCAMPO et al. 201, pg.54). 
Esta identidade também se apresenta nas formas organizativas, na conformação dos conselhos comunitários e titulação de terra coletiva (ARIZA, V. et al, 1999). Ao mesmo tempo a floresta se apresenta "como a inscrição espacial da memória coletiva e como uma referência indenitária forte" (WANDERLEY, 2000, pg. 117).

Wanderley (2000) ao se referir ao rural como categoria de pensamento anota o seguinte:

O rural é uma categoria de pensamento do mundo social, que é, ao mesmo tempo, uma categoria "político-ideológica" e "transacional". Por ela, é possível "compreender a sociedade", "classificar e distinguir as pessoas e as coisas" e "construir uma representação do mundo social em torno do espaço e do tempo". Representação social que, sem dúvida, gera fatos sociais, faz emergir identidades sociais, mobiliza e organiza socialmente pessoas e grupos sociais em torno de reivindicações específicas e ressignifica a história das sociedades (pg. 130).

É nessa direção que se pode reconhecer a floresta húmida tropical como uma categoria do espaço rural, a qual se foi configurando desde os tempos colônias com a chegada dos negros ao Pacifico, e a qual é caracterizada pela continuidade espacial que apresenta seu simbolismo e identidade, elementos que criam o espaço rural das comunidades negras do Pacifico caucano, e que hoje, também, configura-se como um espaço de luta.

\section{CONSIDERAÇÕES FINAIS}

A costa Pacífica no Cauca, habitualmente descrita por sua diversidade biológica, por sua importância ambiental, por seu nível de conservação e por estar habitada por comunidades negras e indígenas, também é caracterizada pela pobreza e violência, o que a configura como uma região única. Sua história e sua geografia explicam sua conformação territorial, seu isolamento e descaso em relação à sua pouca ou nula articulação com o Estado-Nação, o qual, e ao mesmo tempo, possibilitou a conservação de uma rica cultura ancestral e a preservação de seus saberes e tradições a respeito do espaço da Floresta úmida tropical, suas formas particulares de uso da terra, suas técnicas e seus cultivos e seu conhecimento sobre a dinâmica natural da floresta, tem permitido que as pessoas negras vivam, trabalhem e mantenham-se neste espaço no decorrer do tempo.

Na busca por compreender a ruralidade no Pacífico Caucano, se apresentaram as ferramentas metodologicas usadas no transcorrer do trabalho de campo, que junto com entrevistas e mapas mentais, enriqueceram a compreensão do espaço estudado, mostrando que os mapas elaborados manualmente pela comunidade do município de Lopez de 
Micay privilegia o saber local. Esta elaboração manual de mapas foi um processo onde se desenham os territórios a partir de outras perspectivas e desde outras dimensões espaciais, conseguindo assim, a compreensão da dinâmica das relações agrárias que se geram na área de estudo.

Neste contexto, a pesquisa se propôs analisar e reconstruir com a comunidade negra do município de Lopez de Micay o conceito de Ruralidade, o qual só foi possível indagar a partir do saber local e dos processos incessantes de viver nos limites epistêmicos do sistema moderno/colonial (ESCOBAR, 2010:29), de onde a ruralidade é interpretada. Dessa forma, os conceitos de Espaço Aquático de Oslender (2008) e Territórios de Fronteira de Serje (2011), foram conceitos norteadores para considerar a Floresta úmida tropical do Pacífico Caucano como uma categoria espacial, vista desde seu conjunto de significações e identificações, que se materializam neste espaço de floresta. Essa categoria espacial talvez, e como indica Serje (2011), possa ser mais que do uma categoria ou conceito, senão o âmbito de um "verdadero dominio epistemológico, a través del cual se hace posible visualizar la forma en que la alteridad se produce espacialmente, a través de un proceso de estatización y de erotización de lo local, de lo territorial”(308).

É necessário destacar o papel da Cartografia Social como ferramenta e metodologia, a qual tornou possível aos participantes percorrer o espaço aquático, a floresta em suas imaginações, numa espécie de apropriação mental de seu território, o qual oportunizou a discussão dos problemas que a comunidade enfrenta, possibilitando a ressignifição do território (OSLENDER, 2006) e a produção do conhecimento.

Essa construção de conhecimento através do saber local, também é uma crítica ao pensamento de modelo ocidental, o qual com seu discurso e implementação da modernização, que no Pacífico gera-se através da violência e da ameaça de destruição do território negro, tem provocado mudanças no espaço da floresta, o qual tem repercussões frente às construções simbólicas dos negros do Pacífico.

Essa insensibilidade nos instrumentos da modernidade não só tem criado uma tensão entre tradição e a modernidade, senão que tem quebrado com as temporalidades que as comunidades negras têm, devido a sua forte ligação com a floresta (OSLENDER, 2006, pg.254). Já que os tempos e fluxos estabelecidos pelos negros se pauta através das marés sendo este um referencial dotado de significado, o qual pode desaparecer na medida em que a mineração e outras atividades modificam o espaço, ou na medida em que a tradição oral se vê ameaçada ante a chegada de outras formas de conhecimento, que exclui o saber local sobre a dinâmica da floresta. "Así, por ejemplo, categorizaciones sociales como las 
de monte bravo y monte biche, por ejemplo, con la sexuación y gramáticas culturales asociadas, desaparecen para transformarse en reinscripciones y resiginificaciones frente a la inusitada inscripción espacial del monocultivo" (RESTREPO, 2013, pg. 267) de óleo de palma ou palma africana.

Finalmente o que se gera neste estudo é um dialogo de saberes entre um pensamento académico de corte ocidental e o proveniente de una cultura étnica distintiva: a das comunidades negras do Pacifico. Onde se é possível "defrontarmo-nos com a emergência de matrizes de racionalidades outras tecidas a partir de outros modos de agir, pensar e sentir" (PORTO, 2002, pg. 220). Racionalidades essas, que marcam a emergência de territórios epistêmicos que se resinificam e que criam outras formas de ver o mundo.

\section{REFERÊNCIAS}

1. ARIZA, V. E; CHAVARRO, P. M; VARGAS, P. Paisajes vividos, paisajes observados: la percepción territorial en la zonificación ecológica del pacifico colombiano. Bogotá: Editora Gente Nueva, 1999.

2. BOURDIEU, P. O Poder simbólico. Tradução Fernando Tomaz. Rio de Janeiro: Editora Bertrand, 1989.

3. CARNEIRO, M. J. "Rural" como categoria de pensamento. In: Revista do Centro de Estudos Rurais-RURIS, v.2, n. 1, março de 2008.

4. ESCOBAR, A. Territorios de diferencia: Lugar, movimientos, vida, redes. Primera edición en español: Envión editores, octubre de 2010 Traducción: Eduardo Restrepo, Popayán: Samava Impresiones, 2010.

5. LEFEBVRE, H. A produção do espaço. Trad. Doralice Barros Pereira e Sérgio Martins (do original: La production de l'espace. 4e éd.Paris: Éditions Anthropos, 2000). Primeira versão: início - fev.2006.

6. LYNCH, K. La imagen de la ciudad. Barcelona: Gustavo Gili SL, 2008.

7. OCAMPO, P. M; CHENUT, C. P; FÉRGUSON, L. M; MARTÍNEZ, C. M. EL rio: ritmo y fuente de la vida. De las riberas del Atrato a la construcción de lugares de encuentro en Bogota: Caso afrocolombiano desplazados reubicados en la UPZ Tibabuyes, Suba, Bogota, D.C. Bogotá: Universidad Externado de Colombia, Departamento Administrativo de Ciencia, Tecnologia e Innovacion (COLCIENCIAS), 2013.

8. OSLENDER, U. La búsqueda de un contra-espacio: ¿hacia territorialidades alternativas o cooptación por el poder dominante? Geopolítica(s): revista de estudios sobre espacio y poder, vol. 1, núm. 1, 95-114. 2010.

9. OSLENDER, U. Comunidades negras y espacio en el Pacifico colombiano: hacia un giro geográfico en el estudio de los movimientos sociales. Bogotá: Instituto Colombiano de Antropología e Historia ICANH, 2008. 
10. PERALTA, A.J.A. De lo "domestico/manso" a lo "lejano/arisco". Un recorrido por la cartografía simbólica del territorio negro del Chocó. Revista ANTIPODA, Bogota, n. 14, p.113-137, 2012.

11. PORTO, G. C. W. Da geografia às geo-grafias: um mundo em busca de novas territorialidades. In CECEÑA, Ana Esther; SADER, Emir (comps). La guerra infinita Hegemonía y terror mundial. Buenos Aires: CLACSO, pg. 217-256, 2002. Disponível em:http://bibliotecavirtual. clacso.org.ar/ar/libros/cecena/porto.pdf

12. RESTREPO, E. Economia y simbolismo en el Pacifico negro. Tesis de Antropología. Facultad de Ciencias Sociales y Humanas, Universidad de Antioquia. 1996.

13. RESTREPO, E. Etnizacion de la negridad: La invención de las comunidades negras como grupo étnico en Colombia. Popayán: Universidad del Cauca, 2013.

14. PEREZ, E. E. Nueva Ruralidad en Colombia. In GONZÁLES, M. H.; HUACUJA, I.M. (Org). Nueva Ruralidad enfoques y propuestas para America Latina. Mexico: Centros de estudios para el desarrollo rural sustentable y la soberanía alimentaria Camara de Diputados LX Legislatura/ Congreso de la Union, 2006.pg 77-121.

15. PNUD. 2011. Colombia rural. Razones para la esperanza. Informe Nacional de Desarrollo Humano 2011. Bogotá: INDH PNUD.

16. PORTO, G. C. W. Da geografia às geo-grafias: um mundo em busca de novas territorialidades. In CECEÑA, Ana Esther; SADER, Emir (comps). La guerra infinita Hegemonía y terror mundial. Buenos Aires: CLACSO, pg. 217-256, 2002. Disponível em: http://bibliotecavirtual. clacso.org.ar/ar/libros/cecena/porto.pdf

17. SERJE. M. El Revés de la Nación. Territorios Salvajes, Fronteras y Tierras de nadie. Bogotá: Universidad de los Andes, 2011.

18. WANDERLEY, M. A emergência de uma nova ruralidade nas sociedades modernas avançadas - o "rural" como espaço singular e ator coletivo. Estudos Sociedade e Agricultura, 15, outubro 2000, Pg. 87-145.

19. WEST, R. Las tierras bajas del Pacifico colombiano. Tradução Claudia Leal Bogotá, DC. Julio del 2000.

Artigo recebido em 18 de março de 2016.

Artigo aceito em 30 de maio de 2016. 